J. Clin. Chem. Clin. Biochem.

Vol. 18, 1980, pp. 17-21

\title{
A Kinetic Test for the Assay of the C1 Esterase-Inhibitor ${ }^{1}$ )
}

By F. P. Schena, C. Manno,

2nd Clinica Medica, University of Bari,

R. D'Agostino, G. Bruno, F. Cramarossa,

Chimica Generale e Inorganica, University of Bari and

L. Bonomo,

2nd Clinica Medica, University of Bari, Bari, Italy

(Received February 2/July 9, 1979)

Summary: The most satisfactory diagnostic procedure for hereditary angioneurotic oedema is the demonstration of low serum levels of $\mathrm{C} 1$ esterase-inhibitor. A modified method for the assay of this protein is described. It is based on the kinetic measurement of the $\mathrm{C} 1$ esterase-inhibitor when it inhibits the hydrolysis of $\mathrm{N}$-acetyl- $L$-tyrosine-ethyl ester by $\mathrm{C} 1$ esterase. The relative $\mathrm{Cl}$ esterase-inhibitor concentration is based on the initial hydrolytic velocity, which can be evaluated from the $\mathrm{pH}$ change in a short time and within a small range. High reproducibility, cheap instrumentation and short time of analysis are some of the favorable aspects of this method in comparison with the 'end point titrimetric' method. Furthermore, this paper describes the mechanism of inhibition of $\mathrm{C} 1$ esterase by $\mathrm{C} 1$ esterase-inhibitor. The results are indicative of a non-competitive mechanism. The value of the Michaelis-Menten constant, $K_{\mathrm{m}}$, is $0.017 \pm 0.001 \mathrm{~mol} / 1$ at $37^{\circ} \mathrm{C}$, in the optimum pH range 7.2-7.4. An estimate of $K_{\mathrm{I}}$ in arbitrary units is also given.

\section{Kinetischer Test für die Bestimmung des C1-Esterase-Inhibitors}

Zusammenfassung: Das zufriedenstellendste Verfahren zur Diagnostik des hereditären angioneurotischen Ödems ist der Nachweis der erniedrigten Konzentration des C1-Esterase-Inhibitors im Serum. Eine modifizierte Methode zur Bestimmung dieses Proteins wurde erarbeitet. Sie beruht auf der kinetischen Messung des C1-Esterase-Inhibitors, der die von C1-Esterase katalysierte Hydrolyse des Substrats N-Acetyl- $L$-tyrosin-ethylester hemmt. Die relative Konzentration des C1-Esterase-Inhibitors kann aus der Anfangsgeschwindigkeit der Hydrolyse, die in kurzer Zeit und innerhalb eines geringen Bereichs aus der pH-Zeitkurve berechnet wird, ermittelt werden. Hohe Reproduzierbarkeit, billige Ausrïstung und kurze Analysendauer sind einige wichtige Aspekte dieser Methode im Vergleich zur EndpunktTitrationsmethode. Ferner wird der Mechanismus der Hemmung der C1-Esterase durch C1-Esterase-Inhibitor beschrieben. Die Ergebnisse weisen auf einen nichtkompetitiven Mechanismus hin. Die Michaelis-Menten-Konstante $K_{\mathrm{m}}$ beträgt $0,017 \pm 0,001 \mathrm{~mol} / 1$ bei $37^{\circ} \mathrm{C}$ im optimalen $\mathrm{pH}$-Bereich von 7,2-7,4. Ein Schätzwert für die Inhibitorkonstante $K_{1}$ in freigewählten Eịnheiten wird angegeben.

\section{Introduction}

Hereditary angioneurotic oedema is a well defined clinical syndrome characterized by a repeated occurrence of acute attacks of oedema in any organ, skin and mucosae of the upper respiratory and gastrointestinal tracts.

The most satisfactory diagnostic procedure for hereditary angioneurotic oedema is the demonstration of low serum 1) This study was supported in part by Grant No. 78.02281.04 of
Consiglio Nazionale delle Ricêrche, Rome levels of $\mathrm{C} 1$ esterase-inhibitor (1), which modulates the activation of the complement classical pathway. In its absence $\mathbf{C} 1$ activation proceeds autocatalytically and reacts with its natural substrates $\mathrm{C} 4$ and $\mathrm{C} 2$. The enzymatic assay of $\mathrm{C} 1$ esterase-inhibitor is to be preferred to the immunochemical method, since a variant of hereditary angioneurotic oedema is known, which is due to a functional deficiency of the inhibitor $(2,3,4)$. The enzymatic measurement was performed by evaluating the esterolytic activity of the $\mathrm{C} 1$ esterase on the synthetic substrate, $\mathrm{N}$-acetyl- $L$-tyrosine-ethyl ester, 
by microformol titration, as described by Levy \& Lepow (5). Other authors $(6,7)$ have subsequently modified this method based upon the hydrolytic property of $\mathrm{Cl}$ esterase on $\mathrm{N}$-acetyl- $L$-tyrosineethyl ester. $\mathrm{C} 1$ esterase is added to the inhibitor, until hydrolysis is complete, the reaction being followed to the end point with a pH-stat automatic titrator.

This paper describes the kinetic mechanism of the inhibitory effect of the $\mathrm{Cl}$ esterase-inhibitor on the hydrolysis of $\mathrm{N}$-acetyl- $L$-tyrosine-ethyl ester catalysed by $\mathrm{Cl}$ esterase. Furthermore, it presents a modified technique for the assay of $\mathrm{Cl}$ esterase-inhibitor. High reproducibility, cheap instrumentation and quick analysis are some of the favorable aspects of this method.

\section{Materials}

The reactor is stirred magnetically and thermostated by means of a water jacket at $37 \pm 0.1^{\circ} \mathrm{C}$ for $15 \mathrm{~min}$. The $\mathrm{pH}$ is measured and registered with a microelectrode and a pH-meter (E 436 Metrohm Herisau).

Enzyme: purified $\mathrm{Cl}$ esterase (Cordis, Miami), activated with an equal volume of saline solution at $37^{\circ} \mathrm{C}$ for $15 \mathrm{~min}$. The amount of enzyme was expressed in terms of its activity. One unit (U) of $\mathrm{Cl}$ esterase is defined as the amount which liberates $1 \mu \mathrm{mol}$ of acid per min (IUB), under the conditions defined below. The concentration of the activated solution of enzyme is $150 \mathrm{mU} / \mathrm{l}$.

Substrate: N-acetyl-L-tyrosine-ethyl ester $1 \mathrm{~mol} / \mathrm{l}$ in methyl cellosolve (2-methoxy ethanol).

Inhibitor: two types of inhibitor have been used: 1 . pool of normal human sera of blood donors stored at $-70^{\circ} \mathrm{C}$ in a refrigerator (S10) with liquid nitrogen; this preservation is very important, owing to the easy degradation of $\mathrm{Cl}$ esteraseinhibitor, 2. purified $\mathrm{C} 1$ esterase-inhibitor (Cordis, Miami).

\section{Method}

A defined amount $(1100-1200 \mu \mathrm{l})$ of saline solution is added to the reactor together with normal human serum $(0-40 \mu l)$ or purified $\mathrm{Cl}$ esterase-inhibitor $(0-120 \mu \mathrm{l})$; $\mathrm{N}$-acetỳl- $L$-tyrosineethyl ester $1 \mathrm{~mol} / 1$ is slowly added until the final concentration $(0.005-0.067 \mathrm{~mol} / \mathrm{l})$ is attained; during these operations the $\mathrm{pH}$ is maintained at the optimum value in the range 7.2-7.4 by adding small amounts of $0.02 \mathrm{~mol} / 1 \mathrm{NaOH}$. Finally, all the activated enzyme $(300-400 \mu \mathrm{l})$ is added and the $\mathrm{pH}$ is registered. From the slopes of the $\mathrm{pH} /$ time curves the instantaneous velocity of the reaction, $\mathrm{d}\left[\mathrm{H}^{+} \mathrm{J} / \mathrm{dt}\right.$, can be calculated. Reaction rates are determined with the test serum and with a pool of normal sera, and inhibition is expressed as a percentage of that observed with normal serum.

\section{Results}

Hydrolysis of the synthetic substrate (S) initiated by C1 esterase (E) was studied with normal human serum containing $\mathrm{C} 1$ esterase-inhibitor (I), and with a purified inhibitor. The results are illustrated in figures 1 and 4 for the normal human serum and in figure 2 for the purified $\mathrm{C} 1$ esterase-inhibitor.

As shown in figure 1 the amount of hydrogen ions freed, at given substrate and enzyme concentrations, is a linear function of time for a wide range of added amounts of normal human serum $(0-40 \mu 1)$. Identical results were obtained using scale dilutions of purified $\mathrm{C} 1$ esterase-inhibitor instead of normal human serum. The slope of the straight lines of figure 1 represents the instantaneous velocity of the hydrolytic reaction, $\mathrm{d}\left[\mathrm{H}^{+}\right] / \mathrm{dt}$ $[\mathrm{mol} / \mathrm{l} \cdot \mathrm{s}]$, which is effectively independent of time for the first few minutes of the reaction. A longer lasting autocatalytic effect of $\mathrm{Cl}$ esterase present in the normal
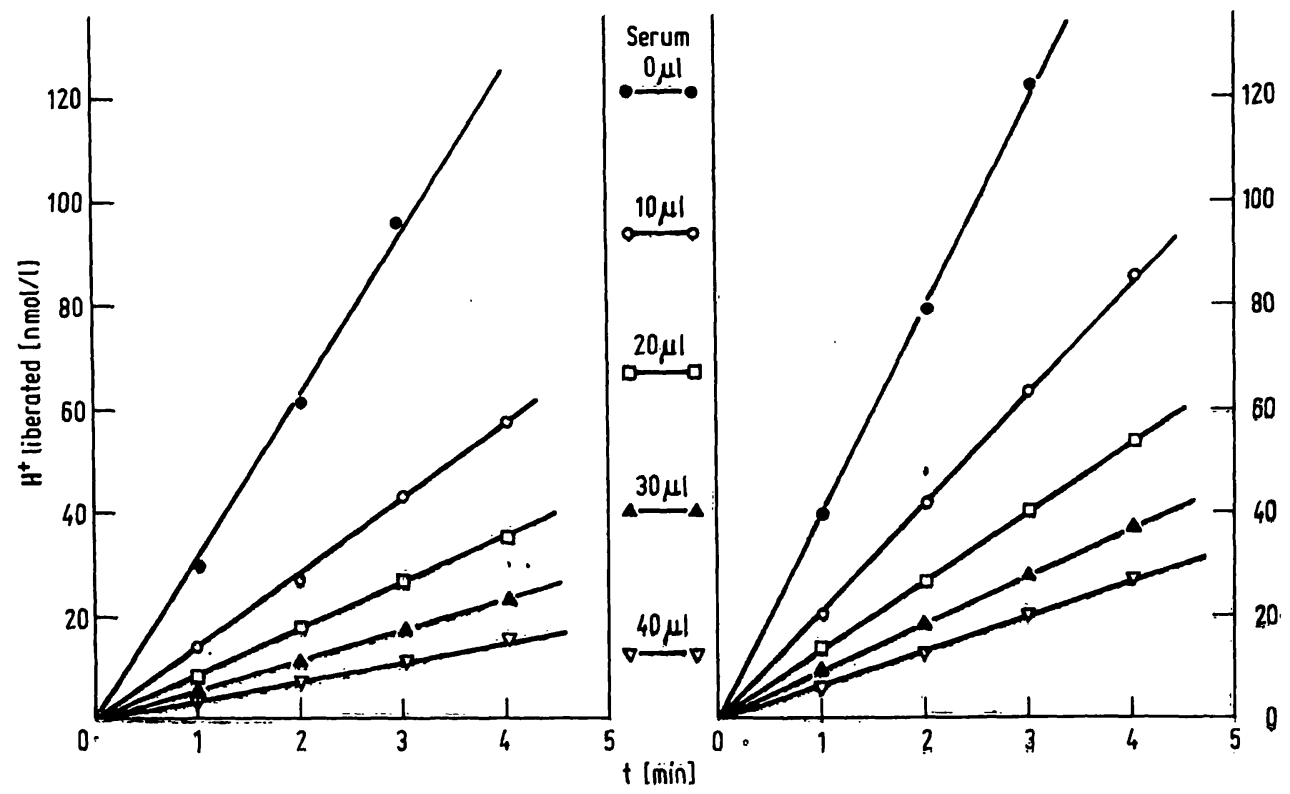

Fig. 1. Hydrolysis of the $\mathrm{N}$-acetyl-L-tyrosine-ethyl ester $0.05 \mathrm{~mol} / \mathrm{l}$ as a function of ( $\mathrm{t}$ ), at various amounts of normal human serum $(\mu l)$, containing $\mathrm{Cl}$ esterase-inhibitor, by $\mathrm{Cl}$ esterase (left: $\mathrm{Cl}$ esterase $=300 \mu 1$; right: $\mathrm{C} 1$ esterase $=400 \mu 1$, corresponding to 30 and $40 \mathrm{mU} / 1$ in the final solutions, respectively). 


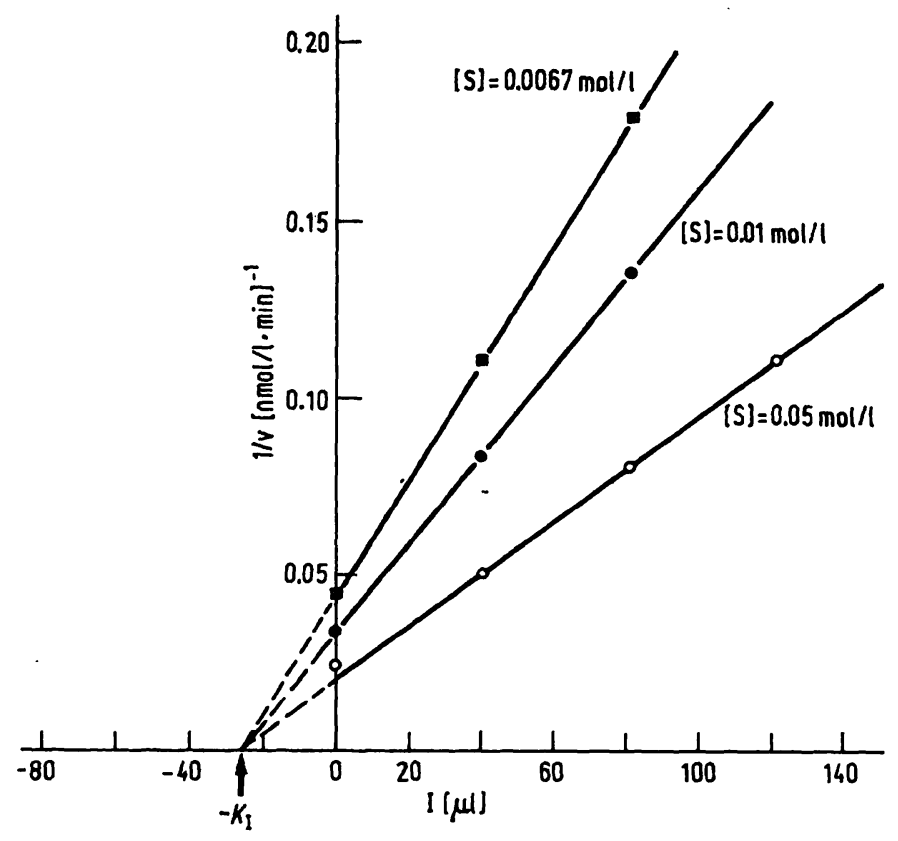

Fig. 2. Inverse of the rate of hydroly sis versus inhibitor $(I=\mu l$ of purified $\mathrm{Cl}$ esterase-inhibitor) at various concentrations of substrate, for calculation of $K_{\mathrm{I}}$. C1 esterase concentration is $40 \mathrm{mU} / \mathrm{l}$. the other hand when analysing with normal human serum, we utilized a substrate concentration $[\mathrm{S}]=0.05 \mathrm{~mol} / \mathrm{l}$, as suggested by Haines \& Lepow (10). The relationship $1 / \mathrm{v}$ versus $I$ is also valid at high substrate concentrations, as shown in figure 2 ; in this study a concentration of [S] $=0.025 \mathrm{~mol} / \mathrm{l}$ gave approximately the same results.

The results are also reported in figure 3 in terms of the direct-linear plot of Eisenthal \& Cornish-Bowden (11). This figure shows that the inhibition mechanism is noncompetitive and provides an accurate estimation of $K_{\mathrm{m}}$.

The linear correlation between $1 / \mathrm{v}$ and the amount of purified $\mathrm{C} 1$ esterase-inhibitor, expressed in $\mu \mathrm{l}$, also holds when the inhibitor is present in the normal human serum (fig. 4). Samples of scale quantities of normal human serum (0-40 $\mu$ l) were tested at an enzyme concentration corresponding to $40 \mathrm{mU} / 1$. Figure 4 represents the calibration plot of the inhibition percentage in respect to pooled normal sera. Twenty normal subjects were tested and they showed a range of variability of $83-126 \%$ pooled normal sera $(\bar{x} \pm 2 S D)$. $\mathrm{C} 1$ esterase-inhibitor in the serum of a patient with hereditary angioneurotic oedema was $43 \%$; it was $18 \%$ in serum when $\mathrm{C} 1$ esterase-inhibitor was inactivated by heating for $30 \mathrm{~min}$ at $59^{\circ} \mathrm{C}$. This latter value confirmed the fact that $\mathrm{C} 1$ esterase-inhibitor is thermolabile (12).

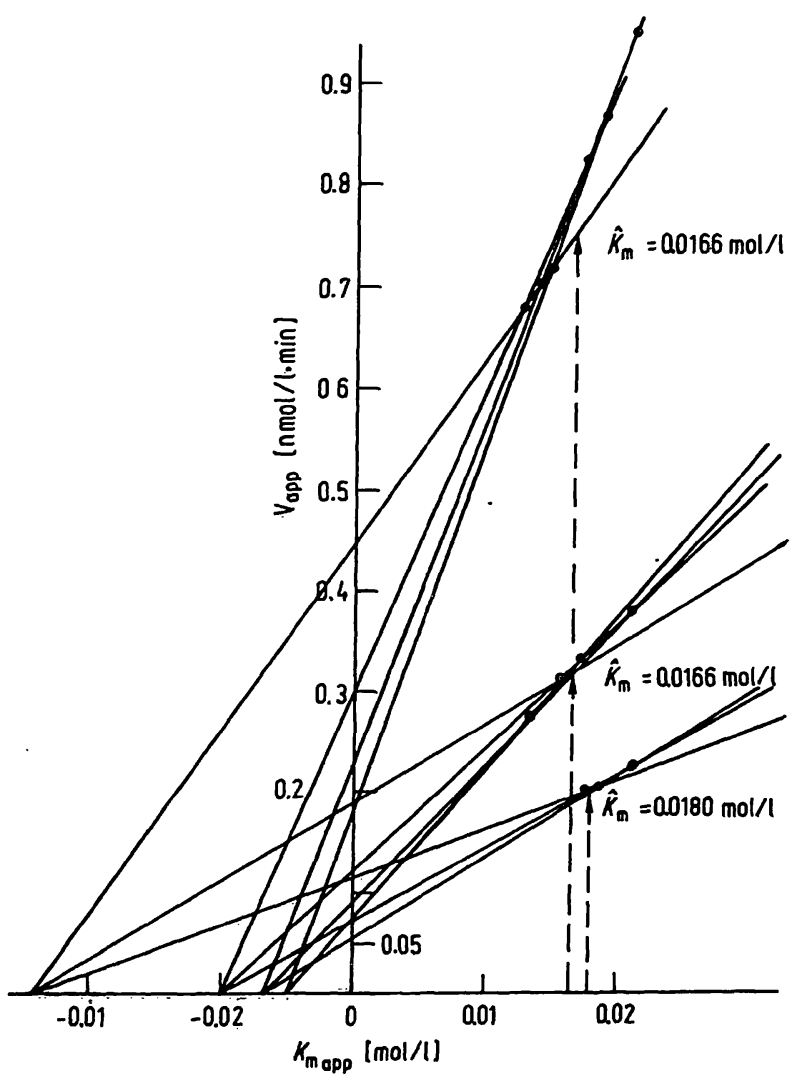

Fig. 3. Direct-linear plot of Eisenthal \& Cornish-Bowden. Each intersection provides an estimate of $\mathrm{V}$ and $K_{\mathrm{m}}$. The shifts of the intersections at the same value of $K_{\mathrm{m}}$ indicate a non-competitive mechanism. 


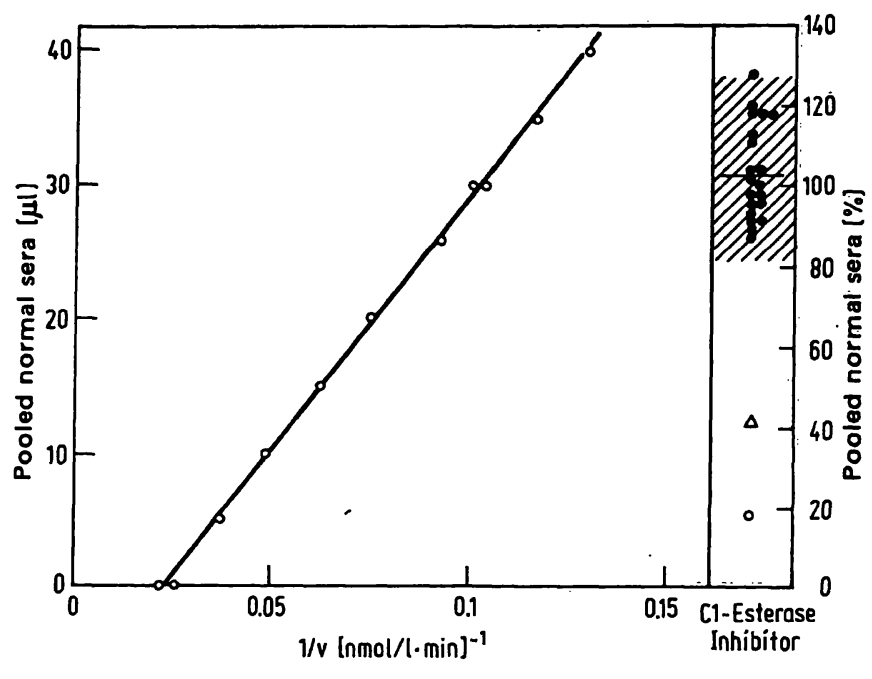

Fig. 4. Calibration plot of percentage inhibition with respect to pooled normal sera. The amount of $\mathrm{C} 1$ esterase-inhibitor ( $\mu$ l of pool of normal sera) as a function of $1 / v .1 / v$ is the inverse of velocity of $\mathrm{N}$-acetyl- $L$-tyrosine-ethyl-ester $(0.05 \mathrm{~mol} / \mathrm{l})$ hydrolysis by $\mathrm{C} 1$ esterase $(40 \mathrm{mU} / \mathrm{l})$. The scale of $\%$ pooled normal sera is shown on the right, where $100 \%$ corresponds to $30 \mu \mathrm{l}$; also the range of variability $(\bar{x} \pm 2 S D)$ determined from 20 blood donors $(\bullet) ;(\Delta)$ patient with hereditary angioneurotic.oedema; $(0)$ human serum heated at $59^{\circ} \mathrm{C}$ for $30 \mathrm{~min}$.

\section{Discussion}

The experimental results compare well with the results reported by Haines \& Lepow (10), who studied the enzyme kinetics in absence of the inhibitor.

Due to various factors in our system and the way the velocity was measured, the effect of $\mathrm{pH}$ on the rate of hydrolysis should be taken into consideration. In the experimental $\mathrm{pH}$-range (7.2-7.4) the activity of the enzyme and the inhibitor are on a plateau $(6.7-8.0)$. In fact, Haines \& Lepow (10) have shown that when the $\mathrm{pH}$ is varied between 6.7 and 8.0 , the $\mathrm{Cl}$ esterase activity towards $\mathrm{N}$-acetyl- $L$-tyrosine-ethyl ester is optimal; Pensky et al (12) found a greater $\mathrm{pH}$-range for the optimum of $\mathrm{Cl}$ esterase-inhibitor function. On the other hand, the results of this study showed that the $\mathrm{pH}$ had no significant effect on the system under the experimental conditions.

Concerning the relationship between the velocity of esterolytic reaction and the inhibitor concentration, the data obtained show that $1 / v$ is linearly related to the $\mu \mathrm{l}$ of normal human serum or the $\mu l$ of purified $\mathrm{C} 1$ esteraseinhibitor. This reaction can be expressed by the equation: $1 / v=K_{1}+K_{2}[I]$, which allows us to measure the inhibition, expressed as \% pooled normal sera. The principle on which this assay is based derives from the mechanism of inhibition. In 1975 Harpel \& Cooper (13) studied the molecular basis of the interaction between
$\mathrm{C} 1$ esterase-inhibitor and $\mathrm{Cl}$ esterase. With SDS gelacrylamide electrophoresis they saw that the enzymeinhibitor complex was in equilibrium with the free enzyme and free inhibitor; no cleavage peptides of the $\mathrm{C} 1$ esterase-inhibitor were found as a consequence of the action of $\mathrm{C} 1$ esterase, suggesting that this was not the real substrate for the enzyme. However, these findings were not sufficient to determine the type of inhibition and the equilibrium present in this system. Although other authors $(10,12)$ had studied the kinetic characteristics of $\mathrm{Cl}$ esterase and some properties of $\mathrm{C} 1$ esteraseinhibitor, these aspects of the problem had not been taken into consideration. The enzymatic dosage suggested by them, which gave way to successive methods, was based on the general ability of $\mathrm{Cl}$ esterase-inhibitor to diminish the hydrolytic activity of the $\mathrm{Cl}$ esterase on $\mathrm{N}$-acetyl- $L$-tyrosine-ethylester while the kinetic problem was not duly taken in to consideration. The experiments carried out in our laboratories with purified $\mathrm{C} 1$ esteraseinhibitor have confirmed the results with human serum, and they have permitted the characterization of the mechanism of $\mathrm{Cl}$ esterase inhibition, and the determination of the Michaelis-Menten constant, $K_{\mathrm{m}}$, and the constant of equilibrium with $\mathrm{I}, K_{\mathrm{I}}$. The results are indicative of a non competitive mechanism of inhibition, as clearly shown in the Dixon plot (fig. 2) as well as in the Eisenthal \& Cornish-Bowden plots (fig. 3). With this directlinear plot the value of $K_{\mathrm{m}}$ is easily calculated as the average of each series of points. The non-competitive mechanism is confirmed by the shift of the common intersection points at a practically constant value of $K_{\mathrm{m}}=17 \mathrm{mmol} / 1$. This value can be compared to $19 \mathrm{mmol} / 1$, obtained by Haines \& Lepow (10).

Based on non-competitive inhibition, a new kinetic assay is suggested in place of the previously reported method (8), which seems to be less rigorous and reproducible. The processes involved in the method reported by Lachmann et al. (8) are in fact complicated by the presence of the phosphate buffer, whose basic component $\left(\mathrm{HPO}_{4}^{2-}\right)$ reacts with the $\mathrm{H}^{+}$freed in the enzymatic reaction, when repeated amounts of $\mathrm{C} 1$ esterase are added. This implies that the 'end point' claimed by Lachmann et al. (8) is attained when enough $\mathrm{Cl}$ esterase is added to overcome the effect of $\mathrm{HPO}_{4}^{2-}$, in addition to that of the inhibitor alone. It is worth noting that one should keep in mind the exact quantity of $\mathrm{HPO}_{4}^{2-}$ present. This factor has been explicitly considered by the authors. Moreover, the repeated sampling of $\mathrm{C} 1$ esterase contributes to the systematic errors, and it decreases the rapidity of the method by a factor of 5 . In contrast, our method is highly reproducible as is shown in the calibration plot of figure 4 , where the regression factor is 0.998 . Furthermore our method is more economic, since it is not necessary to use a complicated pH-stat, but simply a pHmeter connected to a suitable recorder. 


\section{References}

1. Donaldson, V. H. \& Evans, R. R. (1963), Amer. J. Med. 35, $37-44$.

2. Rosen, F. S., Alper, C. A., Pensky, J., Klemperer, M. R. \& Donaldson, V. H. (1971), J. Clin. Invest. 50, 2143-2149.

3. Axelsson, U. \& Laurell, A. B. (1971), Clin. Exp. Immunol. 8, 511-516.

4. De Marchi, M., Jacot-Guillarmod, H., Ressa, T. G. \& Carbonara, A. O. (1973), Clin. Genetics 4, 229-235.

5. Levy, L. R. \& Lepow, I. H. (1959), Proc. Soc. Exp. Biol. Med. $101,608-611$.

6. Laurell, A. B. \& Silboo, R. (1966), Acta Pathol. Microbiol. Scand. 68, 230-242.

7. Hadjiynnaki, K. \& Lachmann, P. J. (1971), Clin. Allergy 1, 221-233.

8. Lachmann, P. J., Hobart, M. J. \& Aston, W. B. (1973), Complement technology. In: Handbook of Experimental Immuno- logy, (Weir, D. M., ed.) 2nd ed., Blackwell Scientific Publ., pp. 5.13-5.14.

9. Lepow, I. H., Naff, G. B. \& Pensky, J. (1963), Mechanism of activation of C'l and inhibition of C'l esterase. In CIBA Foundation Symposium Complement, Churchill, London., pp. 74-98.

10. Haines, A. L. \& Lepow, I. H. (1964), J. Immunology 92, 456-467.

11. Eisenthal, R. \& Cornish-Bowden, A. (1974), Biochem. J. 139, 715-720.

12. Pensky, J., Levy, L. R. \& Lepow, I. H. (1961), J. Biol. Chem. 236, 1674-1679.

13. Harpel, P. C. \& Cooper, N. R. (1975), J. Clin. Invest. 55, 593-604.

Prof. F. P. Schena Clinica Medica II Policlinico University of Bari I-70124 Bari 
